Professor Boyd-Dawkins was elected President; Mr. B. Hobson and Mr. Winstanley, Vice-Presidents ; Mr. W. J. Hall, Secretary ; and Mr. O. B. Leigh, Treasurer; and in addition Mr. C. R. Lindsey, Mr. H. B. Hewlett, and Mr. G. Hickling were appointed members of the Committee.

The meetings are to take place monthly, during the University Session, at the Owens College, and excursions will be arranged to places of geological interest in the Spring and Summer.

\title{
COREFSPONDEITCE.
}

THE LOWER CULM OF NORTH DEVON.

Sir,--In the Geological Magazine, November, 1904, pp. 530-32, appears a Note by Dr. Arthur Vaughan on the above beds.

Never having worked in the Carboniferous Limestone areas of Chepstow, etc., or the foreign equivalents referred to, I am unable to express an opinion on the conclusions arrived at by Dr. Vaughan. But I must take exception to the observations contained in the last paragraph of p. 531 commencing "I further deduce," etc.

The beds from which the fossils north-west of South Molton were collected are the Posidonomya beds, and these fossils occur in calcareous bands intercalated with the Posidonomya shales and limestones. I cannot, therefore, accept the statement that these beds are at a "somewhat lower level" than those of Codden Hill. On the contrary, I believe them to be the continuation of the Venn and Swimbridge beds and therefore above the highest zone of Codden Hill. Dr. Vaughan admits that he is not personally acquainted with the Codden Hill district. May I be allowed to suggest that he makes himself so, when I think he will see that an area such as this is not quite so easily 'zoned.' Or, at least, that the question can hardly be decided on the evidence of a part of the fauna only. It is a mistake, I think, to attempt such a thing without taking into consideration the whole of the fossil evidence, stratigraphy, and lithological character of the rocks.

Tine locality from which the fossils referred to come, should be described as south of North Aller not South Aller. This was an error on the labels of my fossils and no fault of Dr. Vaughan's.

The Close, Barnstaple, J. G. Hamling. November $9 t h, 1904$.

\section{CEPHALOPODA FROM NORTH-WEST FRONTIER OF INDIA.}

Srr,--In my " Note on two Cephalopods obtained by Lieut.-Col. Skinner, R.A.M.C., from the Valley of the Tochi River on the north-west frontier of India," which appeared in the GEOLOGIOAL MaGazine for October last (pp. 490-493), the locality of the Ammonoid (Crioceras?), as given in the explanation of the figures, 